\title{
Study on Municipal Solid Waste Management in Malaysia: Case Study in Kuching, Miri and Sibu
}

\author{
Ling, Song Kai \\ Sibu Education Office, Ministry of Education \\ lingsongkai@hotmail.com
}

\begin{abstract}
Malaysia allocates a lot of money, time and space for the waste management services. However, the recycling programmes has remained unsuccessfull in achieving the set targets. This study was carried out in Kuching, Sibu and Miri municipalities to evaluate the communities' attitude, suitability of collection services and identifying the problems and effectiveness of waste management practices and recycling programmes implemented to date. The waste management practices in three towns were determined. Surveys via questionnaires were used to determine the public awareness and public perception on recycling. Landfill capping effects on greenhouses gases emissions were also studied from three landfills in the areas under study. Standard soil classification was firstly conducted by sieve analyses, in accordance to the American Society of Testing and Materials (ASTM) Method No. 1377. The results deduced from the data on waste recycling and composition, indicated that the composition of solid waste was dominated by food waste. This was followed by old newspapers, mixed papers, plastics, bottles/ glass and aluminium cans. The moisture content and energy value of waste was also determined as it influences the disposal option. Average solid waste generation rate per individual in Sarawak was $0.85 \mathrm{~kg} / \mathrm{person} / \mathrm{day}$. The collection time motion study $\mathrm{Tr}=\mathrm{T}-[\mathrm{Tt}+\mathrm{n}(\mathrm{Td}+\mathrm{Th})+\mathrm{Tb}+\mathrm{T1}$ ] (Corbitt, 1989) showed that the average weight of solid waste collected for the three towns was $323 \mathrm{~kg} /$ worker/collection hour with an efficiency of $65 \%$ of the total collection time. With this finding, it can be concluded that the efficiency of the collection system in Sarawak was quite satisfactory. The soil in Sibu had the highest plastic index (PI). The baseline emission of green house gases (GHG) was determined using the Clean Development Mechanism Project Design Document Form as $B E_{C H 4, S W D S, y}=\varphi \cdot(1-f) \cdot G_{\text {WP }}$ CH $_{4}(1-O X) \cdot \frac{16}{12} \cdot F \cdot D O C_{f} \cdot M C F \cdot \sum_{x=1}^{y} \sum_{j} W_{j, x} \cdot D O C_{j} \cdot e^{-k_{j} \cdot(y-x)} \cdot 1-e^{-k_{j}}$
\end{abstract}

The GHG in Kuching was 14,114 tonnes in first year while for Sibu and Miri it was 5,383 and 5,379 tonnes, respectively. Source separation and recycling behaviour (reduce, reuse and recycle) was analysed with several parameter related to public attitudes. This implies that changing public attitude is an important factor towards improving municipal solid waste management services.

Keywords: Wastes, Household, Recycling, Greenhouse gases

\section{Introduction}

Solid waste and its disposal have rapidly moved to the forefront of public attention in the last two decades. Waste is any unwanted material that does not have any apparent, obvious or significant economic or beneficial value to humans. Solid waste management (SWM) is the practices that considers many aspects such as environmental consideration and public attitudes involved with controlling the generation, storage, collection, transfer and transport, processing and disposal of solid waste (Environmental Management Centre Mumbai, 2007). Municipal solid waste management (MSWM) is one of the major problems being faced by municipalities because it involves a huge expenditure and receives scant attention (Kum et al., 2005). Urban areas in Asia spent USD 25 million per year on SWM and this is likely to increase to USD 47 million per year (APO, 2007).

This study focuses on the SWM data at three different towns in Sarawak, Kuching (representing a city council with privatization concept-Trienekan), Sibu (representing municipal council managed by Local Government) and Miri (representing a city council managed by Local Government). The specified objectives are:

- To determine the current waste management practices in Kuching, Sibu and Miri.

The current issue and full text archive of this journal is available at www.jraspublications.org/index.php/JRAS/issue/archive Journal of Research in Administrative Sciences

VI(II), 5-7, ISSN: 2664-2433 
- To gauge the level of recycling activities and to establish main recycling data by means of questionnaires and source sampling.

- To determine the effectiveness of the collection system using time motion study method.

- To determine the energy value of waste produced, before and after recycling.

- To measure infiltration rate of the covering soil and to predict the amount of GHG emission at the landfill.

\section{Literature Review}

Alam Flora Sdn. Bhd. has been awarded the Privatization concession for the central and Eastern region like Selangor, Pahang, Kelantan and Terengganu. SWM Sdn. Bhd. covers the concession in N. Sembilan, Melaka and Johor. E-Idaman covers mainly the northern part of Peninsular Malaysia namely Perak, Kedah, Penang and Perlis. In Peninsular Malaysia, the amount of SW generated has increased from 16,200 tonnes per day in 2001 to 19,100 tonnes in 2005 (Ghasimi et al., 2010). Tavares et al. (2009), determine the fuel consumption of vehicles that collect and transport MSW from the optimal route. Even though Malaysian attitude towards recycling is improving, only a few practice it (Theng and Raihani, 2007).

The total SW generation is expected to reach 585 million tonnes in 2010 (Agamuthu et al., 2009). Osman et al. (2009) shows that the nation's average $\mathrm{SW}$ generation has increased to $0.8-0.9 \mathrm{~kg} / \mathrm{person} / \mathrm{day}$ while for Kuala Lumpur the amount has reached $1.62 \mathrm{~kg} / \mathrm{person} / \mathrm{day}$. In 2006, about 7.34 million tonnes of SW were generated in Malaysia, enough to fill up 42 buildings (Siraj, 2006). From the 7.34 million tonnes of SW generated, 3.30 million tonnes originated from food waste (Audrey, 2009). Effectiveness of recycling activities is mainly depend on the participation of public. This aspect has no been adequately addressed in Sarawak. This data could be considered as primary data for Sarawak in deciding the suitable technology in waste management. Data on waste recycling rate, energy value and efficiency of waste collection at a City Council managed by the Local Authority, City Council managed by a private contractor and a town managed by the Local Authority is also not available.

Recycling is the recovery of the economic values of materials and energy from wastes that are usually destined for disposal. Recycling is very much encouraged. The higher the recycling rate, the better. However, it's influence:

-In terms of final disposal by incineration is not well discussed. When recyclables are collected, the colorific values of waste as input to incinerator will be very much less. This aspect has not been studied. -Its effect to the landfill is also not well discussed. The green house gases $\left(\mathrm{CH}_{4}, \mathrm{CO}_{2}\right.$ and $\left.\mathrm{H}_{2} \mathrm{~S}\right)$ at landfill will also be reduced by doing recycling. Quantification of the reduction amount is important.

The phrase 'Reduce, Reuse, Recycle' is also taught to children all over the world in the hope of creating a clean environment.

Food waste is the major component contributing to weight, followed by mix paper and mix plastics (Saeed et al., 2009). The calorific value of the Malaysian MSW ranged between 1,500 and 2,600 Kcal/kg and the energy potential from an incineration plant operating based on 1,500 tonnes of MSW/day with an average calorific value of 2,200 Kcal/kg is assessed to be at $640 \mathrm{Kw} /$ day. (Sivapalan, 2003). Recycling may reduce this value. Some studies estimated that landfills contribute to about $80 \%$ of the total methane in Delhi (Talyan et al., 2007). On 30th August 2007, the Solid Waste and Public Cleansing Act 2007 (Act 672) was gazetted with the main aim of the federal takeover of SWM and privatization of solid waste handling. Americans waste enough food every day to fill a 90,000 seat football stadium.

\section{Materials \& Methods}

The research was included three towns in Sarawak, namely Kuching, Sibu and Miri.

- Determination of current solid waste management practices Reports, Interview and discussion with officers about legal framework, organisation structure, storage facilities, collection procedures and quantity of waste disposed and Collection of Waste Characteristics and Composition data at landfill site.

- Solid waste management survey
Questionnaires - Perception of collection services and awareness on recycling.

300 questionnaires was set using Likert system (Severity index) to simplify feedback from respondents. Daily waste generation rate (Waste/person) was determined base on 300 households. Daily waste as received at landfill site.

- Waste composition \& recycling data

The Capture Rate (CR) can be calculated as follows: Capture rate $(\mathrm{CR})=(\mathrm{CRWT} / \mathrm{RWT}) \times 100$

Where CRWT $=$ Recyclable waste in second week RWT $=$ Recyclable waste

Participant Rate $=(\mathrm{X} 1 / \mathrm{X} 2) \times 100$

$X_{1}=$ Total number of respondents who returned the green bags $X_{2}=$ total number of respondents who received the green bags

For the participant rate, total number of respondents who returned the green bags divided by the total number of respondents who received the green bags.

Recycling rate $=$ Capture rate $(\mathrm{CR}) \times$ Participation rate $(\mathrm{PR})$

- Time motion study (Manual and GPS)

Time Motion method (in accordance with Tchnoboglous, et al., 1997). Formulas: $\mathrm{Tr}=\mathrm{T}-[\mathrm{Tt}+\mathrm{n}(\mathrm{Td}+\mathrm{Th})+\mathrm{Tb}+\mathrm{T} 1] \quad$ (Corbitt, 1989)

Where:

$\mathrm{Tr}=$ time on route (collection time)

$\mathrm{T}=$ time for the overall collection operation

$\mathrm{Tt}=$ time to travel between depot and route and return at day's end

$\mathrm{Td}=$ time at disposal site

$\mathrm{Th}=$ round trip haul time from route to disposal site and return to collection area

$\mathrm{Tb}=$ Worker activities

$\mathrm{T} 1=$ time loss for delays

$\mathrm{n}=$ number of trips to disposal site per day

- Landfill capping

Energy content, Btu/lb x $2.326=\mathrm{kJ} / \mathrm{kg}$

Moisture content $(\%)=\underline{(\mathrm{a}-\mathrm{b}) \times 100}$

Where $\mathrm{a}=$ initial mass of sample as delivered $\mathrm{b}=$ mass of sample after drying

Permeability and Plasticity limit test were conducted on the soil cover at landfills.

- Total Greenhouse Gases Emission (GHG):

$B E_{C H 4, S W D S, y}=\varphi(1-f) G W P_{C H 4}(1-O X) \cdot \frac{16}{12} \cdot F \cdot D O C_{f} \cdot M C F \cdot \sum_{x=1}^{y} \sum_{j} W_{j, x} \cdot D O C_{j} \cdot e^{-k_{j} \cdot(y-x)} \cdot 1-e^{-k_{j}}$

Where:

$\mathrm{BE}_{\mathrm{CH} 4, \mathrm{SWDS}, \mathrm{y}}=$ Methane emissions avoided during the year $y$ from preventing waste disposal at the solid waste disposal site (SWDS) during the period from the start of the project activity to the end of the year y $(\mathrm{tCO} 2 \mathrm{e})$ $=$ Model correction factor to account for mode uncertainties $(0.9)$

$\mathrm{f}=\quad=$ Fraction of methane captured at the SWDS and flared, combusted or used in another manner

$\mathrm{GWP}_{\mathrm{CH} 4}=$ Global Warming Potential (GWP) of methane, valid for the relevant commitment period

OX = Oxidation factor (reflecting the amount of methane from SWDS that is oxidised in the soil or other material covering the waste)

$\mathrm{F}=$ Fraction of methane in the SWDS gas (volume fraction) (0.5)

$\mathrm{DOC}_{\mathrm{f}}=$ Fraction of degradable organic carbon (DOC) that can decompose

$\mathrm{MCF}=$ Methane correction factor

$\mathrm{W}_{\mathrm{j}, \mathrm{x}}=$ Amount of organic waste type $j$ prevented from disposal in the SWDS in the year $\mathrm{x}$ (tons)

DOC $_{\mathrm{j}}=$ Fraction of degradable organic carbon (by weight) in the waste type $j$

$\mathrm{k}_{\mathrm{j}}=$ Decay rate for the waste type $j$

$\mathrm{j}=$ Waste type category (index) 
$\mathrm{x}=$ Year during the crediting period: $\mathrm{x}$ runs from the first year of the first crediting period $(\mathrm{x}=1)$ to the year $\mathrm{y}$ for which avoided emissions are calculated $(\mathrm{x}=\mathrm{y})$

$\mathrm{y}=$ Year for which methane emissions are calculated

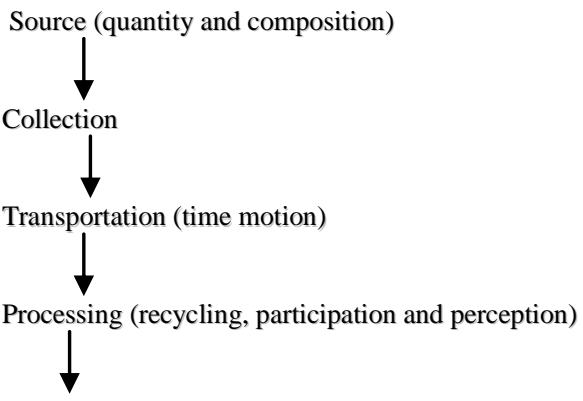

Partial disposal (moisture and energy value)

\section{Fig 1: Process of the Solid Waste Management Results and Discussions}

The study showed that SWM in Sarawak is satisfactory. The most waste generated is food, paper and cardboard. Kuching generated most waste $0.88 \mathrm{~kg} /$ person/day follow by Miri $(0.83 \mathrm{~kg} /$ person/day) and Sibu $(0.82 \mathrm{~kg} /$ person/day). The generation of MSW in Kuching was high due to the Capital City and population activities concentrated. Miri have lowest SW tonnage compared to other city. It may due to incorporation of Lambir transfer station. Miri residents have better awareness in policy and program, problem and reuse in the survey. Effective public awareness programme should be utilize by the mass media. Plastic bags and paper are mostly recyclable. The recycle rate is highest in Sibu $(54.7 \%)$ follow by Miri (43\%) and Kuching (42.7\%). Sibu showed highest recycle rate which proves the success of the recycling campaign. The SW collection efficiency is highest in Miri $(70.7 \%)$ follow by Kuching $(66.7 \%)$ and Sibu $(62.78 \%)$. The SW collection efficiency in Sibu is lower $(62.78 \%)$ if compared to others. It is maybe due to the trucks. The energy value is highest in Kuching and lowest in Sibu with the moisture rate $44.5 \%$. It means Sibu is wet. It is no good for the thermal effect. The permeability in Kuching is $\left(6 \times 10^{-4} \mathrm{~cm} / \mathrm{s}\right)$, Miri $\left(1.77 \times 10^{-3} \mathrm{~cm} / \mathrm{s}\right)$ and Sibu $\left(7 \times 10^{-5} \mathrm{~cm} / \mathrm{s}\right)$. The Plasticity index is the size of the range of water content where the soil exhibits plastic properties. The soil in Sibu landfill had highest Plastic index due to the higher clay content. The Greenhouse gases is highest in Kuching, 14,114 tonnes while Miri and Sibu are around 5,380 tonnes. Kuching had the highest green house gases emission. In conlusion, reducing waste need to start from school. Reducing waste at school instills a culture of environmental responsibility in students. With some creativity and a simple change of habit, schools can reduce waste by following ways such as reduce waste at lunch, reduce paper waste schedule, an exchange or rummage sale and conduct a waste audit.

\section{Conclusions and Recommendations}

SWM data is key in decision making for waste management and current waste management decision made without proper information. Further studies on quantities and composition of all towns in Sarawak and Sabah need to be establish for future planning. It is recommended that survey should be repeated during the festival season to give a more complete picture of SW situation.

\section{Acknowledgments}

We would like to thank all respondents who volunteered to participate in this study. The cooperation of Sarawak Government and Trienekens $\mathrm{Sdn}$. Bhd is exemplary and is most sincerely appreciated.

\section{References}

i. Agamuthu, P., Fauziah, S.H., Khidzir, K. (2009). Evolution of solid waste management in Malaysia: impacts and implications of the solid waste bill, 2007. Journal of Mater Cycles Waste Management, 11 (2), pp. 96 - 103. ii. Asian Productivity Organization (2007). Solid Waste Management: Issues and Challenges in Asia. APO, Tokyo.

iii. Audrey, D. (2009). 'CAP: Food wastage rising with affluence'. New Straits Times. Published 27 November 2009.

iv. Bai, R., Sutanto, M.,(2002). The practice and challenges of solid waste management in Singapore. Waste Management 22, 557567.

v. .Corbitt R.A. (1989). "Standard Hand Book of Environmental Enginering”. New York. McGraw Hill Series.

vi. Enayetullah, I., Sinha, A.H.M.M., Khan, S.S.A.,(2005). Urban Solid Waste Management Scenario of Bangladesh: Problems and Prospects. Waste Concern Technical Documentation, Dhaka, Bangladesh, 18p.

vii. Ghasismi, S.M.D, Tey, B.T., Ronifasla, S \& Sara, G. (2010). Municipal solid waste management at Taman Beringin Transfer Station in Malaysia, In: Lavagnolo, M.C. (2010). A glance at the World. Waste Management, 30 (2), pp. 355-359.

viii. Kasseva, M. E., \& Mbulingwe, S. E. (2005). Appraisal of solid waste collection following private sector involvement in Dar es Salaam City, Tanzania. Habitat International, 29(2), 355-366.

ix. Kassim, S.M., Ali, M., (2006). Solid waste collection by the private sector: households' perspective- Findings from a case study in Dar es Salaam city, Tanzania. Habitat International 30, 769-780.

x. Kum, V., Sharp, A., Harnpornchai, N., (2005). Improving the solid waste management in phnom pench city: A strategic approach. Journal of Waste Management 25 (1), 101-109.

xi. Osman Nuri $\mathrm{Ag}^{-} \mathrm{dag}$., (2009). Comparison of old and new municipal solid waste management systems in Denizli, Turkey. Pamukkale University, Engineering Faculty, Environmental Engineering Department, 20020 Denizli, Turkey

xii. Saeed, M.O., Mohd. Nasir, H., Mujeebu, M.A. (2009). Assessment of municipal solid waste generation and recyclable materials potential in Kuala Lumpur, Malaysia. Waste Management, Vol.29 (7), pp.2209-2213.

xiii. Siraj, M. (2006). Waste Reduction: No Longer an Option but a Necessity: in Bernam.

xiv. Talyan, V., Dahiya, R.P., Anand, S., Sreekrishnan, T.R. (2007). Quantification of methane emission from municipal solid waste disposal in Delhi. Resource Conservation and Recycling 50 (3), pp.240-259.

xv. Tavares, G., Zsigraiova, Z., Semiao,V \& Carvalho,M.G. (2009). Optimisation of MSW collection routes for minimum fuel consumption using 3D GIS modeling. Waste Management. 29, (3), pp. 1176-1185.

xvi. Theng, L.C., \& Raihani, C.M. (2007). Public's Role in Solid Waste Management. IMPAK (4). Department of Environment, Malaysia.

xvii. Thapa, G.B., (1998). Lessons learned from solid waste management in Kathmandu, Nepal. Habitat International 22 (2), 97-114. 